International Journal of Electrical Engineering and Technology (IJEET)

Volume 12, Issue 5, May 2021, pp. 197-206, Article ID: IJEET_12_05_019

Available online at https://iaeme.com/Home/issue/IJEET? Volume $=12 \&$ Issue $=5$

ISSN Print: 0976-6545 and ISSN Online: 0976-6553

DOI: 10.34218/IJEET.12.5.2021.019

(C) IAEME Publication

Scopus Indexed

\title{
PV BASED NEGATIVE OUTPUT SUPERLIFT LUO CONVERTER FOR GRID CONNECTED SYSTEM USING FUZZY LOGIC CONTROLLER
}

\author{
Nishant $S$ \\ Research Scholar, Electrical and Electronics Engineering, \\ St. Joseph's College of Engineering, Chennai, Tamilnadu, India. \\ D. Tamilselvan \\ Research Scholar, Electrical and Electronics Engineering, \\ M.I.E.T Engineering, Trichy, Tamilnadu, India. \\ Prasad H \\ Research Scholar, Electrical and Electronics Engineering, \\ St. Joseph's College of Engineering, Chennai, Tamilnadu, India \\ Dr. T.D. Sudhakar \\ Professor, Electrical and Electronics Engineering, \\ St. Joseph's College of Engineering, Chennai, Tamilnadu, India
}

\begin{abstract}
Photovoltaic based power generation is employed to meet the increasing demand for energy by cleaner means. These PV cells when connected in series should have identical electrical characteristics. For this, converter circuits are employed. A negative output super lift Luo converter (NOSLC) aims at producing negative voltages of comparatively higher range than conventional types. The voltage ranges are obtained at a lower gain value of 0.7. The voltage building can be done using super lift technique where the output voltage rises in geometric progression which results in high voltage gain with reduced ripples. This makes it much suitable for connecting with grid systems. In this paper, fuzzy logic controller is used to obtain better voltage control. The performance of $P V$ based NOSLC with and without fuzzy control have been simulated and compared using MATLAB/SIMULINK.
\end{abstract}

Key words: Fuzzy Logic Controller (FLC), High Gain Converter, PV Cell, Negative Output Super lift Luo Converter (NOSLC)

Cite this Article: Nishant S, D. Tamilselvan, Prasad H and T.D. Sudhakar, PV Based Negative Output Superlift LUO Converter for Grid Connected System using Fuzzy Logic Controller, International Journal of Electrical Engineering and Technology (IJEET), 12(5), 2021, pp. 197-206.

https://iaeme.com/Home/issue/IJEET?Volume=12\&Issue=5 


\section{INTRODUCTION}

Amongst all the recently developed and the already available renewable resources, the most highly suggestible and the prevalent type is solar energy. This is because of its clean and pure generation of energy and the source abundancy [1]. Though solar power generation has such advantages, on the other hand, there are a few disadvantages too. PV cells have very low voltage rating of about $0.5 \mathrm{~V}$ per cell. In order to obtain higher output voltages, these PV cells have to be connected in series. Under such circumstances, the cells that have been connected in series should have identical electrical properties. Practically, maintenance of identical electrical properties is difficult. This would eventually result in ripples at the output voltage and current which thereby leads to reduced efficiency at the output [2]. A negative output super lift Luo converter basically boosts the input DC voltage in a geometric progression manner [3], [4]. The most important reason for adopting the super lift technique is that, much higher output voltages can be obtained with lesser gain values when compared to the other voltage building techniques for converters [5]. At the same time, the ripple content in the output voltage and current are reduced and relatively high output voltage gain is obtained.

\section{OPERATION OF NOSLC}

The circuit diagram of the NOSLC is shown in Fig.1.The circuit consists of a MOSFET switch S, Inductor L1, Diodes D1 and D2, Capacitors C1 and C2, and a load resistance R [4]. The design values for the negative output super lift Luo converter are derived based on the considerations [6] as follows: The input voltage $\left(\mathrm{V}_{\mathrm{S}}\right)$ to the NOSLC is taken as $12 \mathrm{~V}$ which is provided by a DC source. The output voltage $\left(\mathrm{V}_{\mathrm{o}}\right)$ for the load $\mathrm{R}$ of $100 \Omega$ is obtained as $36 \mathrm{~V}$.

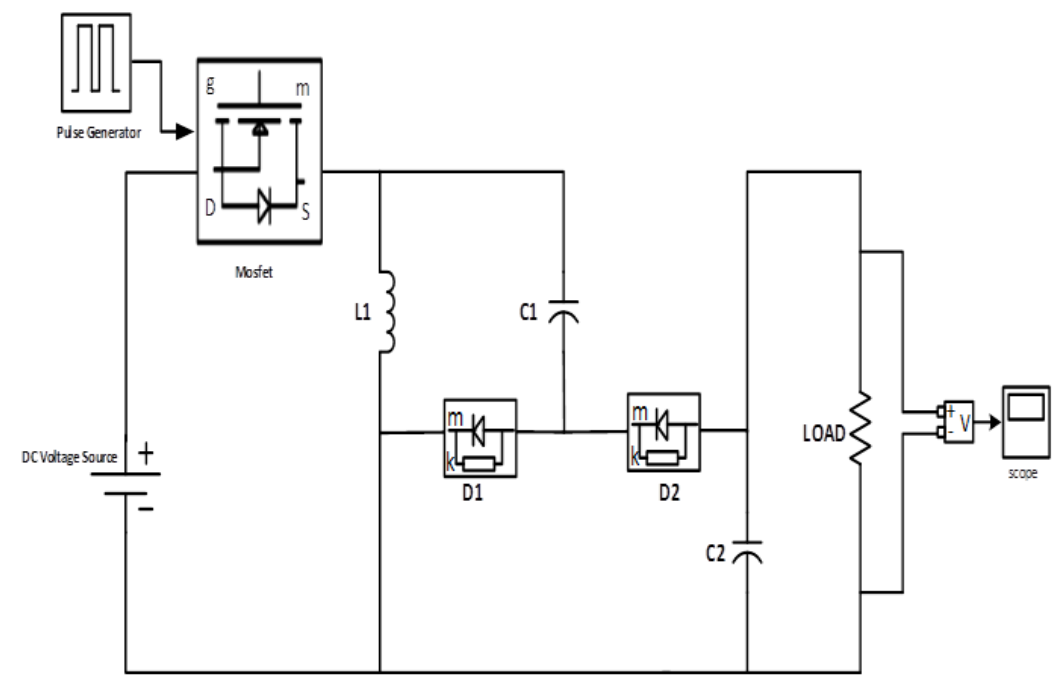

Figure 1 Circuit Diagram of NOSLC

The value for gain $(\mathrm{K})$ is derived from,

$$
\frac{\mathrm{V}_{0}}{\mathrm{~V}_{\mathrm{S}}}=\frac{1}{1-\mathrm{K}}
$$

Thus, 
Nishant S, D. Tamilselvan, Prasad H and T.D. Sudhakar

$$
\begin{aligned}
& 1-\mathrm{K}=\frac{\mathrm{V}_{\mathrm{S}}}{\mathrm{V}_{\mathrm{O}}}=\frac{12}{36} \\
& \mathrm{~K}=1-\frac{12}{36}=0.666 \\
& \mathrm{~K}=0.666
\end{aligned}
$$

The operating frequency $\left(\mathrm{f}_{\mathrm{s}}\right)$ of the NOSLC is $50 \mathrm{kHz}$.

The output current $\mathrm{I}_{\mathrm{o}}$ is obtained from,

$$
\begin{aligned}
& \mathrm{V}_{\mathrm{O}}=\mathrm{I}_{\mathrm{O}} \mathrm{R}_{\mathrm{O}} \\
& \mathrm{I}_{\mathrm{O}}=\frac{\mathrm{V}_{\mathrm{O}}}{\mathrm{R}_{\mathrm{O}}}=\frac{36}{100}=0.36 \mathrm{~A}
\end{aligned}
$$

Using $V_{S} I_{S}=V_{O} I_{O}$ for

$$
\mathrm{I}_{\mathrm{S}}=\frac{\mathrm{V}_{\mathrm{O}} \mathrm{I}_{\mathrm{O}}}{\mathrm{V}_{\mathrm{S}}}=\frac{36 * 100}{12}=1.08 \mathrm{~A}
$$

Let $5 \%$ be the ripple conduct in the output current.

Thus,

$$
\begin{aligned}
\Delta \mathrm{i}_{\mathrm{L} 1} & =5 \% \text { of } \mathrm{I}_{\mathrm{S}} \\
\Delta \mathrm{i}_{\mathrm{L} 1} & =\frac{5}{100} * 1.08 \\
\Delta \mathrm{i}_{\mathrm{L} 1} & =0.054
\end{aligned}
$$

Variation ratio of inductor current,

$$
\begin{aligned}
& \xi_{1}=\frac{\Delta_{\mathrm{iL} 1} / \mathrm{L}}{\mathrm{I}_{\mathrm{L} 1}}=\frac{\mathrm{K}(1-\mathrm{K})}{\mathrm{G}_{1}} \frac{\mathrm{R}}{2 \mathrm{fL} 1} \\
& \text { The gain, } \mathrm{G}_{1}=\frac{\mathrm{V}_{\mathrm{O}}}{\mathrm{V}_{\mathrm{S}}}=\frac{36}{12} \\
& \mathrm{G}_{1}=3
\end{aligned}
$$

The value of inductor $L_{1}$ is calculated using the formula,

$$
\begin{aligned}
\mathrm{L}_{1} & =\frac{\mathrm{K}(1-\mathrm{K})}{\mathrm{G}_{1}} \frac{\mathrm{RI}_{\mathrm{L} 1}}{2 \mathrm{f}^{\Delta \mathrm{I}_{\mathrm{L} 1} / 2}} \\
\mathrm{~L}_{1} & =\frac{0.666(1-0.666)}{3} * \frac{100 * 1.08}{2 * 50000 * 0.054 / 2} \\
\mathrm{~L}_{1} & =2.96592 * 10^{-3} \mathrm{H}
\end{aligned}
$$

Assuming $5 \%$ of ripple in output voltage, the value of $\Delta V_{O}$ is, 
PV Based Negative Output Superlift LUO Converter for Grid Connected System using Fuzzy Logic Controller

$$
\Delta \mathrm{V}_{\mathrm{O}}=5 \% \text { of } \mathrm{V}_{\mathrm{O}}=\frac{5}{100} * 36=1.8 \mathrm{~V}
$$

Variation ratio of output voltage,

$$
\varepsilon=\frac{\Delta \mathrm{V}_{\mathrm{O}} / 2}{\mathrm{~V}_{\mathrm{O}}}=\frac{1-\mathrm{K}}{2 \pi \mathrm{fc} \mathrm{c}_{2}}
$$

The expression of $\mathrm{C}_{2}$ is given as,

$$
\mathrm{C}_{2}=\frac{1-\mathrm{K}}{2 \pi \mathrm{f}} \frac{\mathrm{V}_{\mathrm{O}}}{\Delta \mathrm{V}_{\mathrm{O} / 2}}=\frac{(1-0.666) * 36}{50000 \pi * 1.8}
$$

The values of both the capacitances are equal and thus, $\mathrm{C}_{1}=\mathrm{C}_{2}$

$$
\mathrm{C}_{1}=43.29 * 10^{-6}
$$

Table 1 Design values for Negative output super lift luo converter

\begin{tabular}{|l|c|c|}
\hline \multicolumn{1}{|c|}{ Parameters Name } & Symbol & Values \\
\hline Supply Voltage & $\mathrm{V}_{\mathrm{S}}$ & $12 \mathrm{~V}$ \\
\hline Output Voltage & $\mathrm{V}_{\mathrm{o}}$ & $36 \mathrm{~V}$ \\
\hline Inductor & $\mathrm{L}_{1}$ & $2.96592^{*} 10^{-3} \mathrm{H}$ \\
\hline Capacitor & $\mathrm{C}_{1}$ & $43.29 * 10^{-6} \mathrm{~F}$ \\
\hline Capacitor & $\mathrm{C}_{2}$ & $43.29 * 10^{-6} \mathrm{~F}$ \\
\hline Load Resistance & $\mathrm{R}$ & $100 \Omega$ \\
\hline Duty Cycle & $\mathrm{K}$ & 0.666 \\
\hline
\end{tabular}

\section{PV SUBSYSTEM}

As stated earlier, large number of PV cells are connected in series in order to produce higher magnitudes of output voltage [7]. For this paper, the PV cells are arranged in such a way that it produces open circuit voltage of $12 \mathrm{~V}$ and short circuit current of $10.62 \mathrm{~A}$ as derived in the design procedure. The PV subsystem is designed as follows:

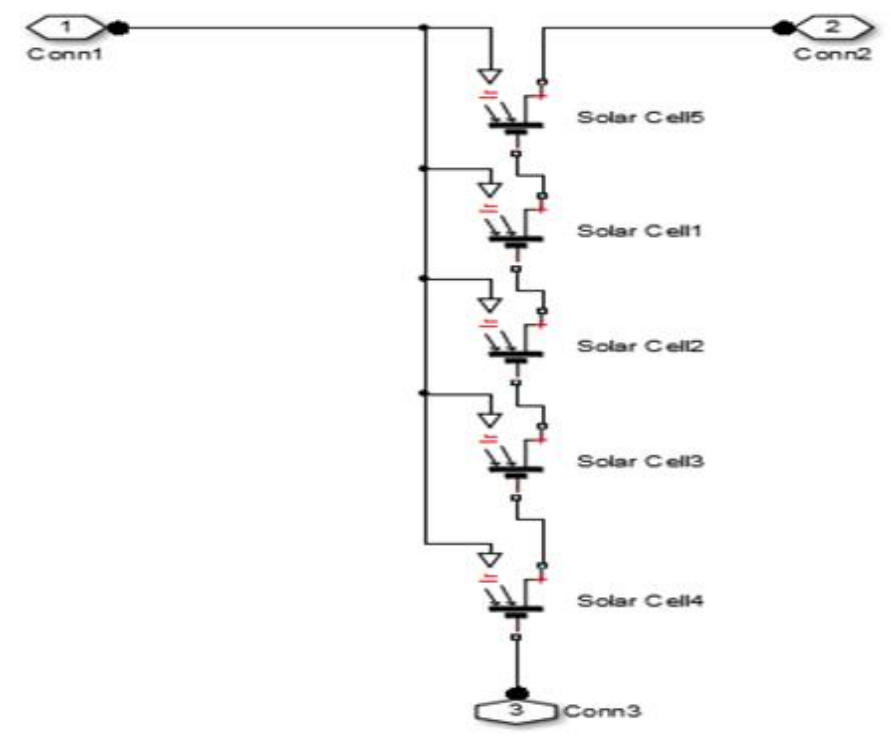

Figure 2 Circuit Diagram of NOSLC 
In Fig.2 Three subsystems containing such solar cells are connected in series. This arrangement produces an output of rating $4 \mathrm{~V}, 10.62 \mathrm{~A}$ for each subsystem. The signals from the voltage and current sensor are converted using a controlled current source. This system is followed by a filter circuit. Thus, the total voltage produced by this PV subsystem is $12 \mathrm{~V}$ and current is 10.62A which is shown in Fig.3. This is fed as input to the NOSLC.

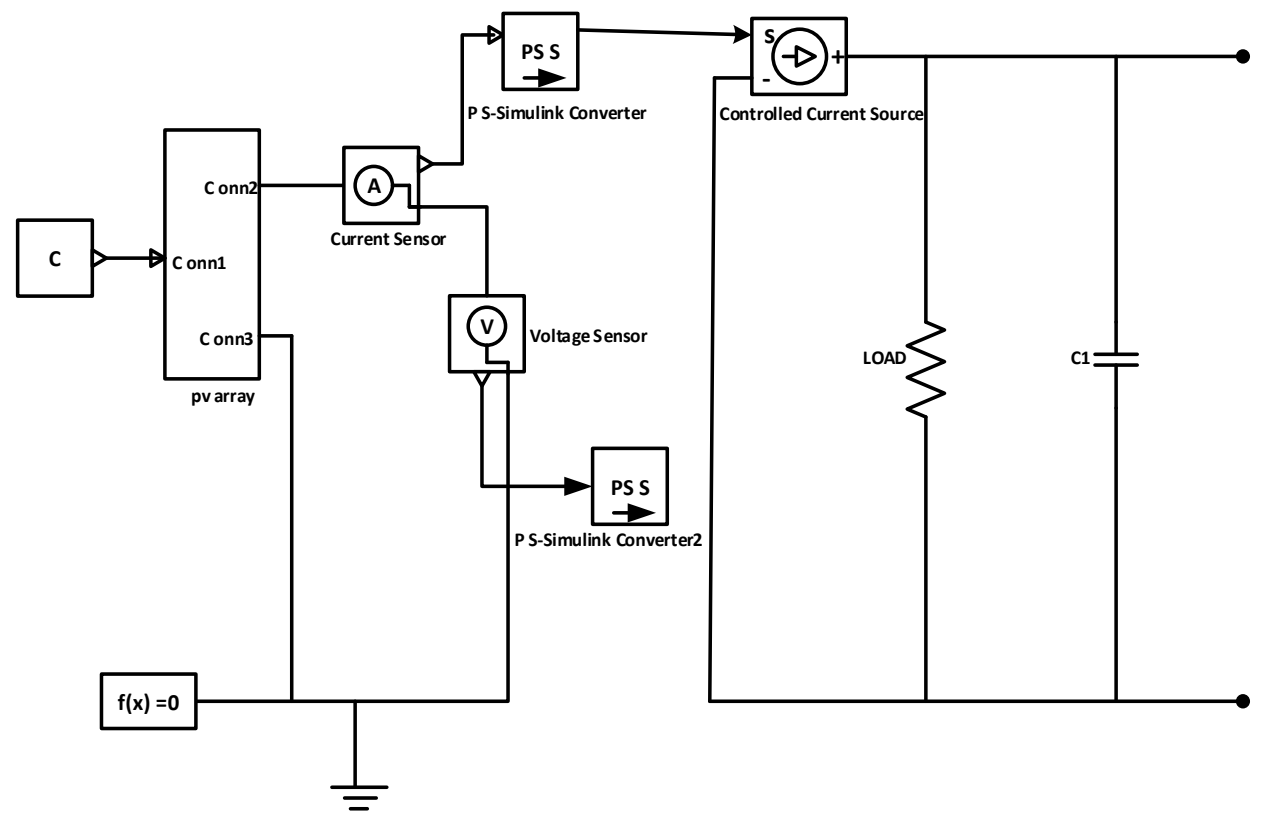

Figure 3 Solar Subsystem

\section{OPEN LOOP CONFIGURATION}

Initially, the open loop configuration for the proposed PV based NOSLC has been designed according to the derived circuit parameter values. The model for the open loop system is as shown in Fig.4.

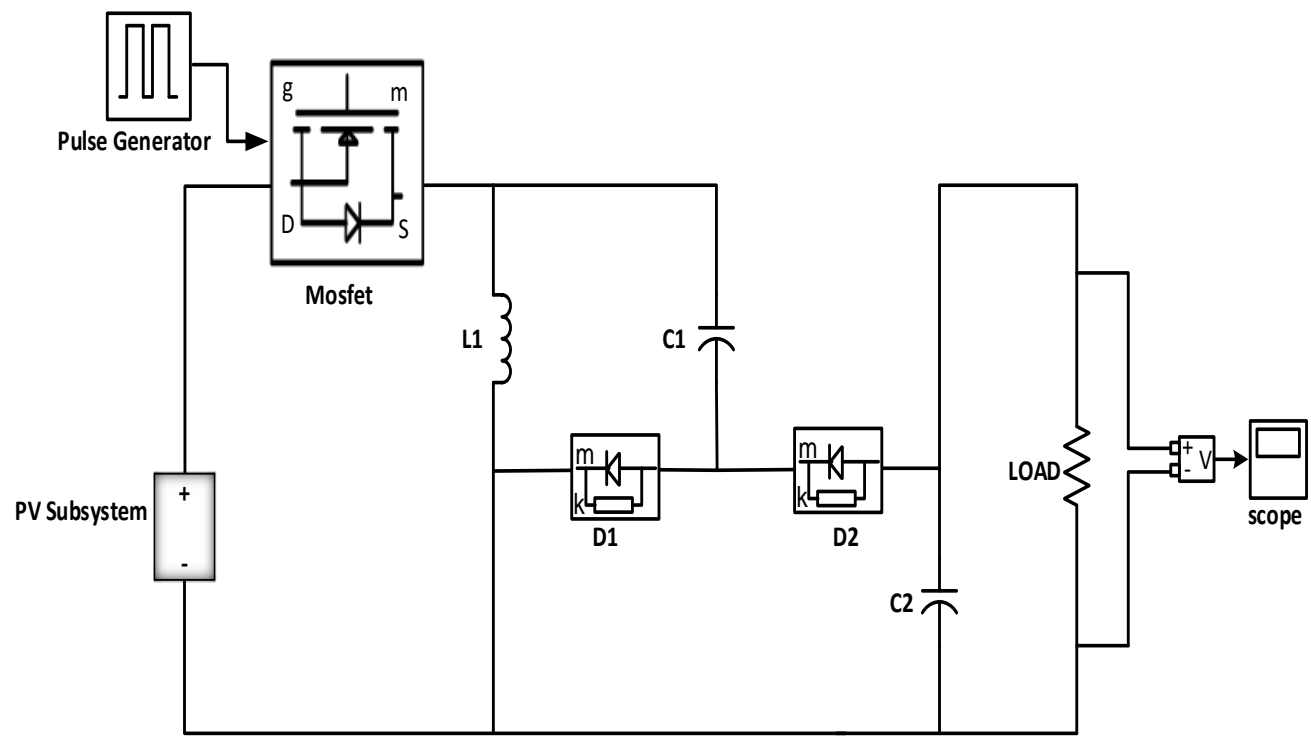

Figure 4 Circuit diagram for open loop

When this PV fed NOSLC is operated at $12 \mathrm{~V}$ input supply and switching frequency of 50 $\mathrm{kHz}$, the output voltage obtained is about $-36.02 \mathrm{~V}$. The simulated output voltage is shown as below in Fig.5., 


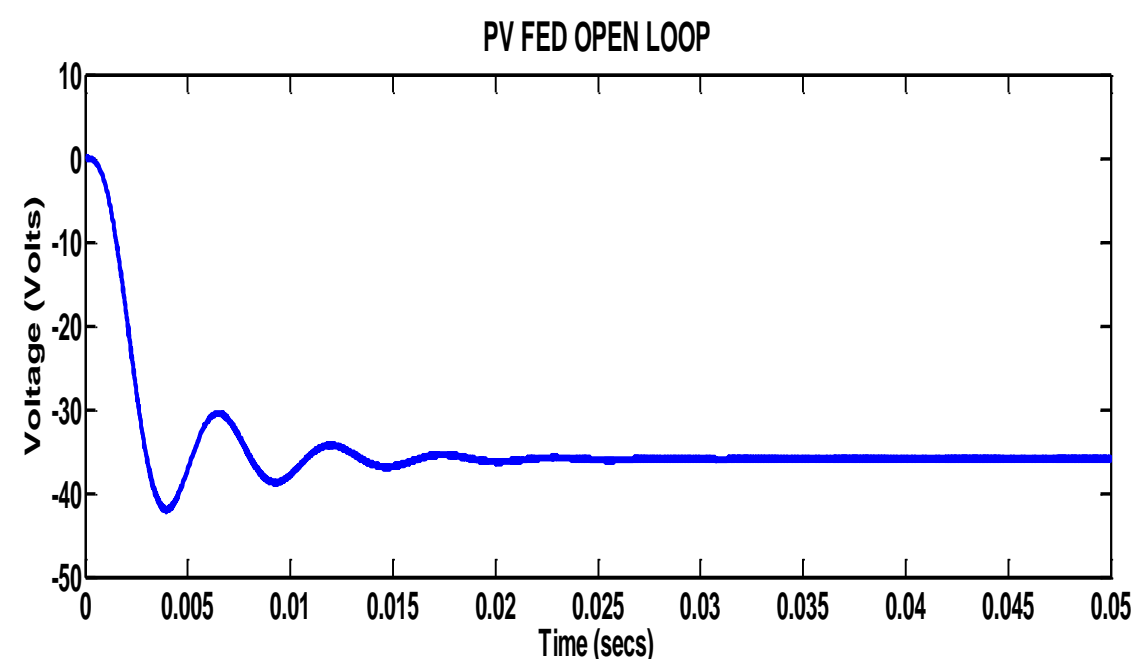

Figure 5 Output voltage for PV fed open loop

From this Fig.5, we can infer that initially there are oscillations and ripples displacing the output voltage for about $6 \mathrm{~V}$ from the required output voltage and stabilizes further. This major disadvantage of uncontrolled voltage of open loop system demands for a better control technique. Thus, closed loop for NOSLC is designed.

\section{CLOSED LOOP CONFIGURATION}

Closed loop provides voltage control over the generated output due to the implementation of feedback system provided as the switching gate pulse to the MOSFET. This ensures better performance of the converter by reduced ripples in the output. The MATLAB simulation for the closed loop voltage control for PV fed NOSLC is given in Fig.6.

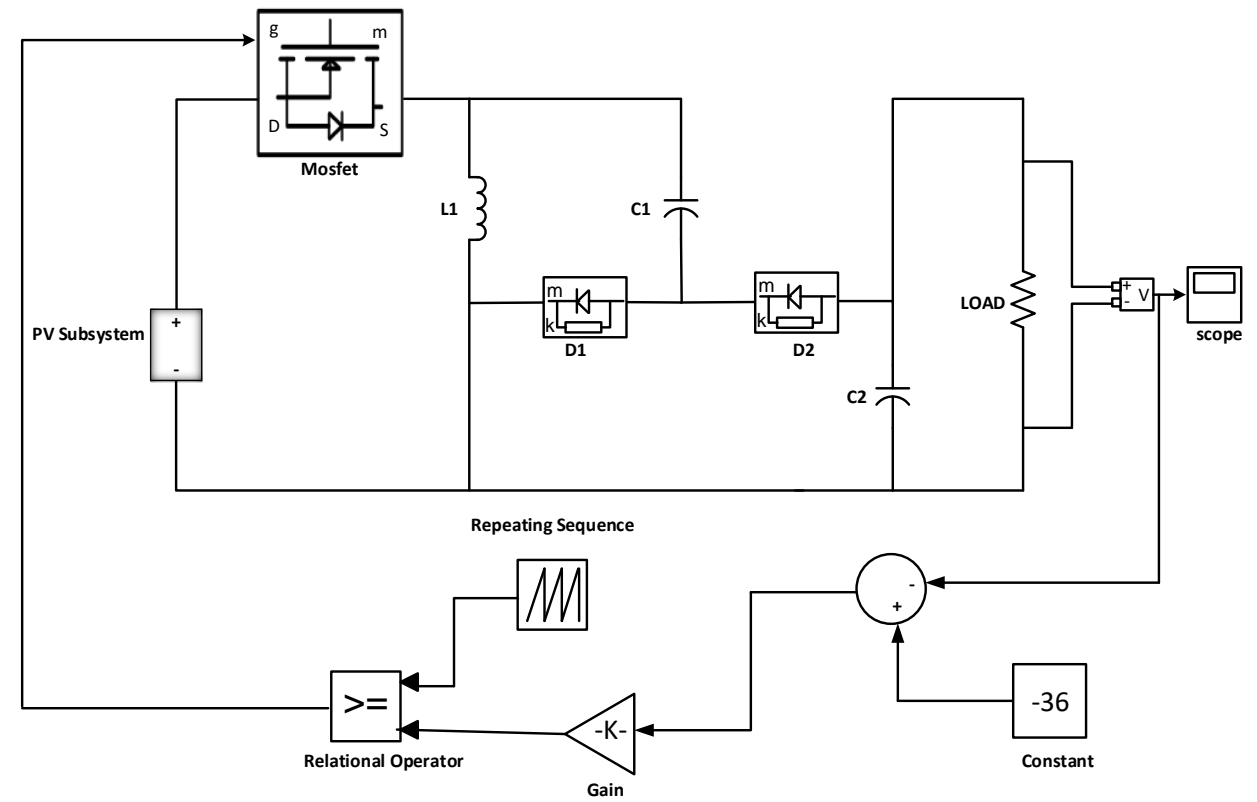

Figure 6 Circuit diagram for closed loop with gain

From the scope output of MATLAB simulation, we can observe that the transient instability and the ripples in the output voltage have been reduced comparatively to the open loop type. 
PV FED CLOSED LOOP CONTROL

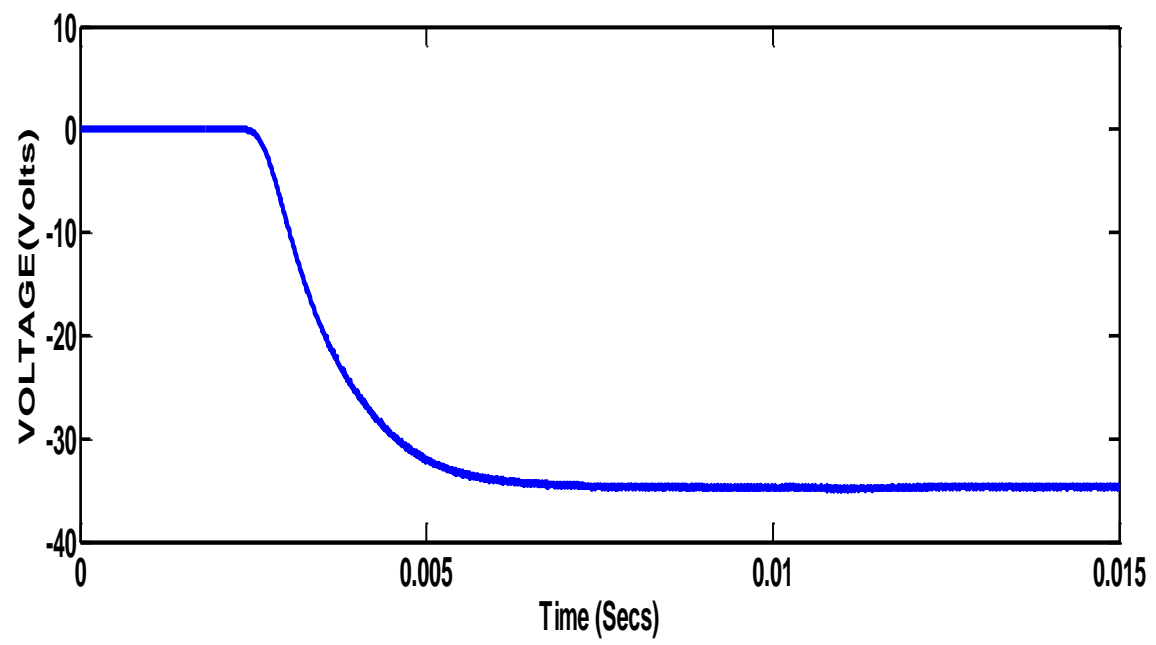

Figure 7 Output voltage for PV fed closed loop

\section{FUZZY LOGIC CONTROL}

To obtain further precise and accurate output values, fuzzy logic (FL) control is employed. The theory of fuzzy sets relates to classes of objects with unsharp and imprecise boundaries in which membership is a matter of degree [8]. The FL involves variables, which are much linguistic rather than numerical and thus exploits the tolerance for imprecision. This fuzzy controller adapts to varying operating points and controls the output voltage of the NOSLC using Mamdani style inference system. Duty cycle(k) is obtained as the output variable, when the error value (e) is fed to controller. This paper aims at controlling the output voltage of the PV based NOSLC and to provide better output performances when compared to that of general closed loop voltage control [9]. The input variable is divided into nine groups as follows: NS (Negative Small), NM (Negative Medium), NB (Negative Big) and NBB (Negative Big Big), PBB (Positive Big Big), PB (Positive Big), PM (Positive Medium), PS (Positive Small), Z (Zero). Similarly, the output variable is also divided into nine groups with the same names. A set of rules has been developed and the output has been determined using fuzzy controller, with these input variables and output variables.[10].

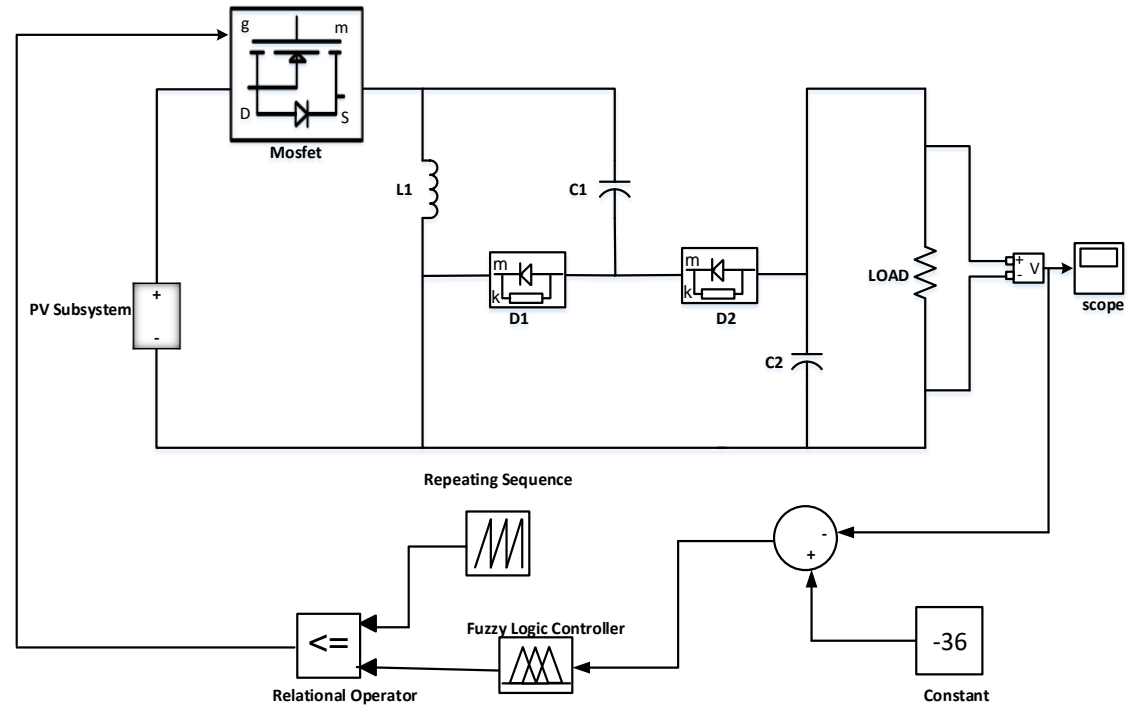

Figure 8 Circuit diagram for fuzzy control 
PV Based Negative Output Superlift LUO Converter for Grid Connected System using Fuzzy Logic Controller

The membership function plots for both input and output variables are depicted as below:

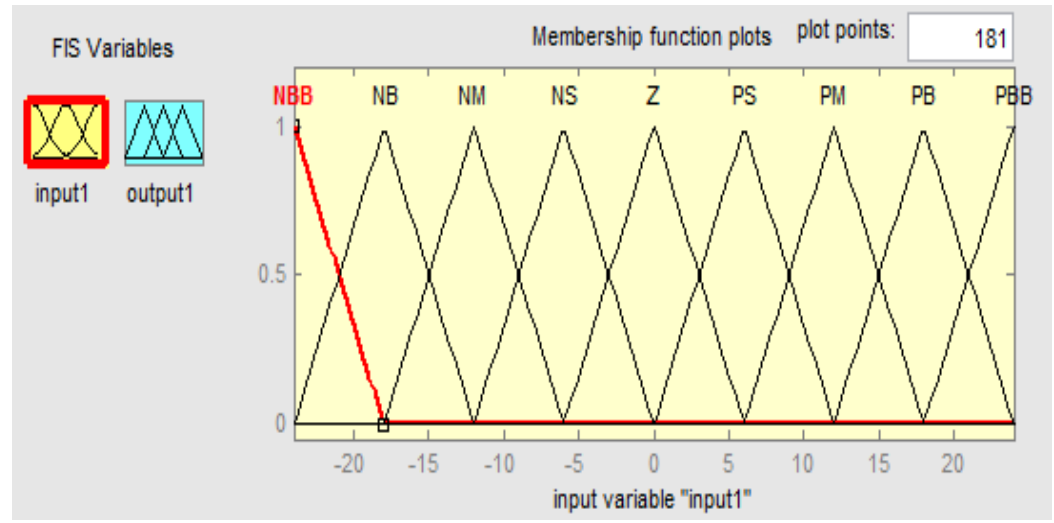

Figure 9 Ruler view: Membership function plot of error[e]

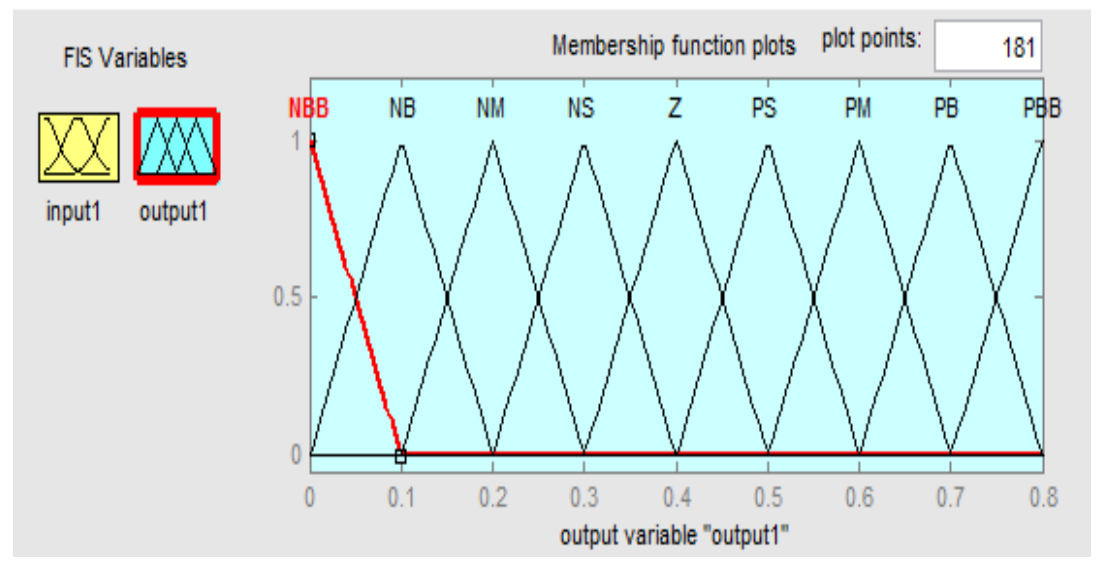

Figure 10 Ruler view: Membership function plot of gain [K]

Table 2 FIS Editor Values

\begin{tabular}{|c|c|c|c|c|}
\hline $\mathbf{V}_{\text {ref }}$ & $\mathbf{V}_{\mathbf{o}}$ & Error & $\mathbf{K}$ & $\begin{array}{c}\text { FIS Editor } \\
\text { values }\end{array}$ \\
\hline 36 & 24 & 12 & 0.5 & 0.5 \\
\hline 36 & 25 & 11 & 0.52 & 0.516 \\
\hline 36 & 26 & 10 & 0.5384 & 0.531 \\
\hline 36 & 27 & 9 & 0.5555 & 0.55 \\
\hline 36 & 28 & 8 & 0.5714 & 0.569 \\
\hline 36 & 29 & 7 & 0.5862 & 0.584 \\
\hline 36 & 30 & 6 & 0.6 & 0.6 \\
\hline 36 & 31 & 5 & 0.6129 & 0.602 \\
\hline 36 & 32 & 4 & 0.625 & 0.606 \\
\hline 36 & 33 & 3 & 0.6363 & 0.614 \\
\hline 36 & 34 & 2 & 0.647 & 0.635 \\
\hline 36 & 35 & 1 & 0.6571 & 0.652 \\
\hline 36 & 36 & 0 & 0.6666 & 0.669 \\
\hline
\end{tabular}

Using these fuzzy rules, the output obtained from simulating is shown in Fig.11. 


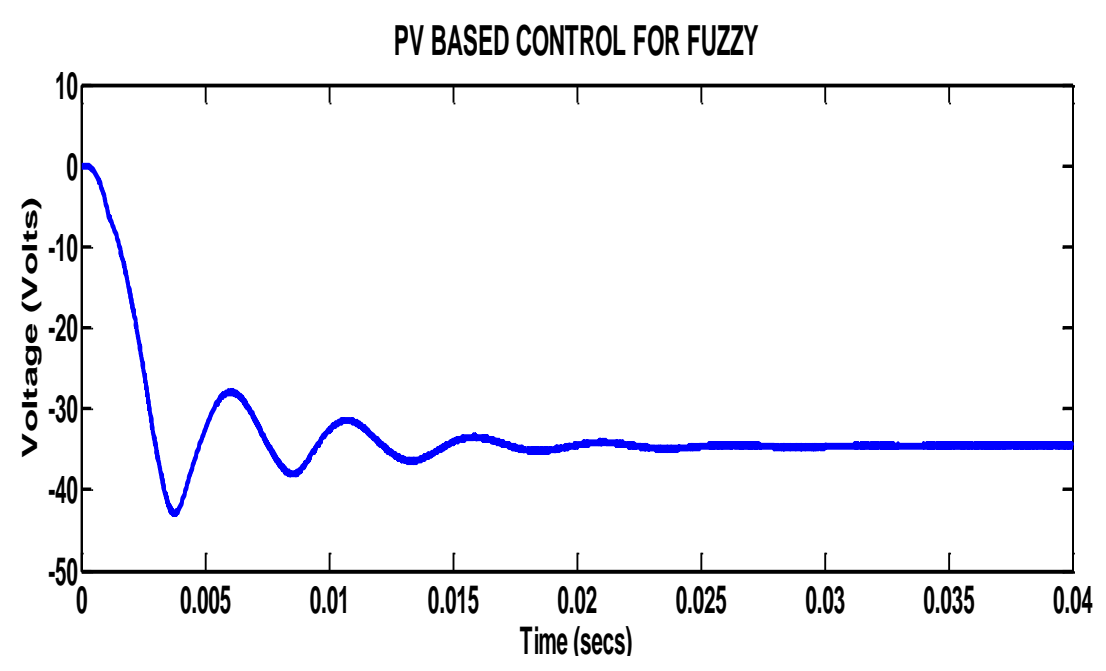

Figure 11 Output voltage for PV based fuzzy control

\section{CONCLUSIONS}

This paper has implemented the design and testing of the NOSLC with open loop and closed loop. Two closed loop method such as voltage control and fuzzy logic control effectively done and it is simulated in MATLAB environment. In this article for the various value of the duty cycle the output voltage measured with minimized error. The $\mathrm{K}$ values change from 0.5 to 0.6 and the voltage at the load side varied from $24 \mathrm{~V}$ to $36 \mathrm{~V}$ for the supply voltage $12 \mathrm{~V}$. Negative output super lift Luo converter performance with fuzzy logic control have reduced the ripples, transient instability and faster response to produce the output voltage with improved gain and less losses. The simulation results of output voltage for fuzzy logic control is obtained and verified.

\section{REFERENCES}

[1] Naveen Shankarappa, Mufassireen Ahmed, Shashikiran N, Dr. H Naganagouda. Solar Photovoltaic Systems - Applications \& Configurations, International Research Journal of Engineering and Technology vol 04 Aug 2017.

[2] Bansal, S., Saini, L. M., \& Joshi, D. (2012). Design of a DC-DC converter for photovoltaic solar system. 2012 IEEE 5th India International Conference on Power Electronics (IICPE).

[3] Luo F. L. "Negative Output Luo-Converters, Voltage Lift Technique" IEE Proceedings on Electric Power Applications, Vol. 146, No. 2, March 1999, pp.208-224.

[4] Luo F. L. and Ye H. "Chapter 17, DC/DC Conversion Techniques and Nine Series LuoConverters" of the "Power Electronics Handbook" Edited by Rashid M. H., Academic Press, San Diego, USA, August 2001.

[5] Fang Lin Luo, Senior Member, IEEE, and Hong Ye, Member, IEEE, "Negative Output Super Lift Converters", IEEE Transactions on Power Electronics, vol. 18, no. 5, September 2003.

[6] Fang Lin Luo, Hong Ye, “Advanced DC converters”, CRC Press, Second Edition, "Chapter-4, Negative-Output Super-Lift Luo-Converters".

[7] Md.W.Shah, Robert L.Biate "Design and Simulation of Solar PV Model Using Matlab/Simulink" International Journal of Scientific \& Engineering Research, Volume 7, Issue 3, March-2016 
PV Based Negative Output Superlift LUO Converter for Grid Connected System using Fuzzy Logic Controller

[8] Haripriya, T., Parimi, A. M., \& Rao, U. M. (2013). Modeling of DC-DC boost converter using fuzzy logic controller for solar energy system applications.2013 IEEE Asia Pacific Conference on Postgraduate Research in Microelectronics and Electronics (PrimeAsia).

[9] Dola Sinha Fuzzy based DC/DC boost converter design to enhance efficacy of photovoltaic application. International Journal of Mechanical and Production Engineering Research and Development (IJMPERD) Special Issue, 421-428, Jun 2018.

[10] Muthukaruppasamy,S. and Abudhahir, A. Indirect Output Voltage Control in Negative Output Elementary Super Lift Luo Converter Using PIC plus FLC in Discontinuous Conduction Mode. Circuits and Systems, 7, 3685-3704, Sep 2016. 